FACTA UNIVERSITATIS

Series: Physical Education and Sport, Vol. 17, No 2, 2019, pp. 427 - 436

https://doi.org/10.22190/FUPES191018038P

Research article

\title{
BODY COMPOSITION, PHYSICAL FITNESS, NUTRITIONAL HABITS AND KNOWLEDGE ABOUT FOOD AND NUTRITION IN FEMALE STUDENTS OF PHYSICAL EDUCATION AND MEDICINE-RELATED COURSES
}

\author{
UDC 796.005.132 \\ 614.253 .4
}

\section{Helena Popławska, Agnieszka Dmitruk, Wojciech Holub}

Faculty of Physical Education and Health in Biala Podlaska,

Jozef Pilsudski University of Physical Education in Warsaw, Poland

\begin{abstract}
The aim of this research was to compare body composition, physical fitness, nutritional habits and knowledge about food and nutrition between female students of physical education (PE) and those studying nursing and physiotherapy. The study was carried out in 2018 and included 137 female PE students and 115 female nursing and physiotherapy students from Biala Podlaska. Body composition was measured with the use of the bioelectrical impedance method. Physical fitness was assessed with the use of the Eurofit test battery. Nutritional habits and knowledge about food and nutrition were assessed using the KomPAN questionnaire which made it possible to determine two indices: the pro-healthy diet index (pHDI-10) and nonhealthy diet index (nHDI-14). Differences in body composition, physical fitness and nutritional habits were assessed using the Student's t-test or Mann-Whitney $U$ test. Differences in the level of nutritional knowledge between the examined groups were assessed with the $\chi^{2}$ test. Female PE students manifested healthier body composition and higher levels of physical fitness. The level of knowledge about food and nutrition was sufficient in the majority of the study participants. Mean indices of the pro-healthy and non-healthy diet fell within the range of low intensity of nutritional features.
\end{abstract}

Key words: Body Build, Physical Fitness, Nutrition, Knowledge about Nutrition, Students

\footnotetext{
Received October 18, 2019/ Accepted November 04, 2019

Corresponding author: Helena Popławska

Faculty of Physical Education and Health in Biala Podlaska, Jozef Pilsudski University of Physical Education in Warsaw, St. Marymoncka 34, 00-968 Warszawa 45, Poland

Phone: + 48 (22) 8345614 •E-mail: helena.poplawska@awf-bp.edu.pl 


\section{INTRODUCTION}

Diet, attitude to stimulants (mainly to alcohol and tobacco), the ability to cope with stress and physical activity are elements of lifestyle which exert the greatest influence on health. Research on the diets of various population groups indicate that basic nutritional rules are rarely followed. Nowadays, human diet is characterised by excessive amounts of fat, including saturated fatty acids and cholesterol, as well as an insufficient intake of vitamins, minerals and fiber (Mazurek et al., 2016; Pérusse-Lachance, Treblay, \& Drapeau, 2010). Engagement of adults in various forms of physical activity is also insufficient. They spend too much time in a sedentary position, usually in front of a computer screen or watching TV (Joshi, Cole, \& Overton, 2016). Weakening of motor abilities increases hypokinesia that leads to obesity; obesity endangers health, and moreover fosters motor inefficiency; this leads to the spiral of causative events that endanger public health (Uzunovic et al., 2019). The above negative behaviours noted in society lead to changes in body composition which increase the prevalence of overweight and obesity and to a decrease in physical fitness followed by disorders of the musculoskeletal system (Gosh \& Bouchard, 2017; Jakičić, \& Otto, 2006; Podstawski, 2013; Saczuk, Wasiluk, Wilczewski, \& Wilczewski, 2016). According to the Eurostat research (2014), 64.1\% of the men and $46.7 \%$ of the women in Poland were overweight, while $18.8 \%$ of the men and $15.9 \%$ of the women were obese.

One of the most significant social groups in terms of the future of every country is constituted by the youth, particularly those who are in the final stage of education (university education) and will soon take responsibility for their country. Students who often change their place of residence while studying have a possibility to make their own choices; however, these choices are not always appropriate. Numerous authors have proved that academic youth often have an irregular lifestyle, turn to addictions and make nutritional errors (Feldman, Harvey, Holowaty, \& Shortt, 1999; Joshi et al., 2016; Tsitsimpikou et al., 2018).

The aim of this research was to compare body composition, physical fitness, nutritional habits and knowledge about food and nutrition between female students of physical education (PE) and those studying nursing and physiotherapy.

\section{METHODS}

\section{Participants}

The study was carried out in 2018 within the statutory research project DS.284 and included 137 female PE students, aged 21.33 \pm 1.56 years (Mean \pm SD), which made up the first group from the Faculty of Physical Education in Biala Podlaska (part of Jozef Pilsudski University of Physical Education in Warsaw), and 115 female nursing and physiotherapy students, aged 21.65 \pm 2.06 years (Mean \pm SD), which made up the second group from the State School of Higher Education in Biala Podlaska. All the measurements and treatments were performed in accordance with the ethical standards laid down in the Declaration of Helsinki.

\section{Body composition and morphologic characteristics}

Body composition was assessed with the use of the bioelectrical impedance method. In order to make the measurements, body composition analyser IOI 353 with JAWON 
MEDICAL software was used. It made it possible to determine the percentage and kilogram values of fat tissue, fat-free tissue $(\mathrm{kg})$, muscle mass $(\mathrm{kg})$, bone tissue mass $(\mathrm{kg})$, total amount of water in the body (\%), and the level of visceral fat tissue (index).

Body height was measured with a height measuring device attached to the body composition analyser. Body mass was measured with the use of the same device. On the basis of the obtained results, BMI was calculated.

\section{Physical fitness}

Physical fitness was assessed with the use of EUROFIT Physical Fitness Test Battery (Eurofit, 1988) that involved performing 8 physical fitness tests (handgrip strength - in kilograms, standing broad jump - in centimetres, bent arm hang - in seconds, sit-ups number of repetitions in 30 seconds, 10 x 5 m shuttle run - in seconds, plate tapping - in seconds, sit and reach - in centimetres, flamingo balance - number of falls in $60 \mathrm{~s}$ ).

\section{Nutritional habits}

Nutritional habits and knowledge about food and nutrition were assessed with the use of the KomPAN questionnaire (Gawęcki, 2014) and the suggested procedure of analysing nutritional data. In order to assess the quality of the diet in a complex manner, the authors of the KomPAN put forward two indicators. One of them focuses on food with a potentially positive influence on health (pHDI-10), while the other one concerns unhealthy food (nHDI-14). The groups of products included in the pHDI-10 and nHDI-14 are listed in Figures 1 and 2. The frequency of consuming each group of food products included in the pro-healthy and non-healthy diet indicators is presented as times per day, according to the data included in Table 1.

Table 1 Recommended values of the frequency of consuming meals in the KomPAN questionnaire

\begin{tabular}{lc}
\hline Categories of consumption frequency & $\begin{array}{c}\text { Daily frequency } \\
\text { (times/day) }\end{array}$ \\
\hline Never & 0 \\
1-3 times per month & 0.06 \\
Once a month & 0.14 \\
A few times per month & 0.5 \\
Once a day & 1 \\
A few times per day & 2 \\
\hline
\end{tabular}

Source: Gawęcki (2014)

In order to compare the frequency of consuming particular products included in the pHDI-10 and nHDI-14 between female PE students and female students of medicinerelated courses, mean numbers of times of consuming each of the analysed food products were calculated in these groups.

With the use of the aforementioned questionnaire, the knowledge of the examined students about food and nutrition was also assessed. Each correct response was granted 1 point, while each wrong answer or the answer "hard to say" was granted 0 points. On the basis of the sum of points scored by every study participant, the level of nutritional knowledge was determined (good: 17-25 points; sufficient: $9-16$ points; insufficient: 0-8 points). 


\section{Statistical Analysis}

Differences in body composition, physical fitness and nutritional habits were assessed using the Student's t-test (with normal distribution of the results in both groups) or the Mann-Whitney $U$ test (when the distribution of results in at least one group did not show normal distribution characteristics). Differences in the level of nutritional knowledge between the examined groups were assessed with the $\chi^{2}$ test. Calculations were made with the use of the Statistica.12 software.

\section{RESULTS}

The analysis of differences in body composition between the groups of students revealed that nursing and physiotherapy students manifested higher percentage and kilogramme values of fat tissue and a higher visceral fat tissue index. PE students had greater body height, muscle mass and fat-free body mass. In turn, no big differences in total body mass, BMI, bone tissue mass and total amount of water in the body were observed. Statistically significant differences between the compared groups of students were noted only in body height, $\%$ fat tissue and visceral fat tissue (Table 2).

Table 2 Somatic measurements and body composition of PE students and students of medicine-related courses

\begin{tabular}{|c|c|c|c|c|c|c|}
\hline \multirow[t]{2}{*}{ Analyzed parameters } & \multicolumn{2}{|c|}{$\begin{array}{l}\text { Physical } \\
\text { education }\end{array}$} & \multicolumn{2}{|c|}{$\begin{array}{l}\text { Medicine-related } \\
\text { courses }\end{array}$} & \multicolumn{2}{|c|}{$\begin{array}{l}\text { Significance of } \\
\text { differences test }\end{array}$} \\
\hline & $\bar{x}$ & SD & $\bar{x}$ & SD & $\mathrm{t} / \mathrm{Z}$ & $\mathrm{p}$ \\
\hline Body height (cm) & 167.69 & 6.61 & 165.02 & 6.38 & $3.14^{1}$ & $0.02^{*}$ \\
\hline Body mass (kg) & 62.60 & 11.00 & 62.57 & 11.08 & $0.15^{2}$ & 0.88 \\
\hline BMI $\left(\mathrm{kg} / \mathrm{m}^{2}\right)$ & 22.26 & 3.20 & 22.97 & 3.61 & $1.59^{2}$ & 0.11 \\
\hline Fat tissue $(\%)$ & 24.53 & 6.31 & 26.48 & 7.13 & $2.41^{2}$ & $0.02^{*}$ \\
\hline Fat tissue (kg) & 15.84 & 6.77 & 17.35 & 7.65 & $1.66^{2}$ & 0.10 \\
\hline Muscle mass (kg) & 44.22 & 5.08 & 43.11 & 3.48 & $1.48^{2}$ & 0.14 \\
\hline Visceral fat & 1.61 & 1.27 & 1.95 & 1.46 & $2.58^{2}$ & $0.01^{*}$ \\
\hline Bone tissue mass (kg) & 2.37 & 0.26 & 2.31 & 0.18 & $1.52^{2}$ & 0.13 \\
\hline Fat-free body mass (kg) & 46.58 & 5.34 & 45.38 & 3.66 & $1.57^{2}$ & 0.12 \\
\hline Total amount of water in a body $(\%)$ & 32.84 & 3.90 & 32.02 & 2.97 & $1.37^{2}$ & 0.17 \\
\hline
\end{tabular}

Key: 1 - Student's t test; 2 - Mann-Whitney U test; *statistically significant difference at $\mathrm{p} \leq 0.05$

Differences regarding the students' body composition and their selection of university courses were related to differences in their physical fitness levels. Students of medicinerelated courses manifested lower results in all the physical fitness tests except for the handgrip strength test. The differences between the groups proved to be statistically significant in all the tests except for handgrip strength and sit and reach tests (Table 3). 
Table 3 Physical fitness of PE students and students of medicine-related courses

\begin{tabular}{lrrrrrr}
\hline Physical fitness test & \multicolumn{2}{c}{$\begin{array}{c}\text { Physical } \\
\text { education }\end{array}$} & \multicolumn{2}{c}{$\begin{array}{c}\text { Medicine-related } \\
\text { courses }\end{array}$} & \multicolumn{2}{c}{$\begin{array}{c}\text { Mann-Whitney } \\
\text { U test }\end{array}$} \\
\cline { 2 - 7 } & \multicolumn{1}{c}{$\bar{x}$} & \multicolumn{1}{c}{ SD } & \multicolumn{1}{c}{$\bar{x}$} & \multicolumn{1}{c}{ SD } & \multicolumn{1}{c}{ Z } & \multicolumn{1}{c}{$\mathrm{p}$} \\
\hline Hand grip (kg) & 34.52 & 5.64 & 34.67 & 4.65 & 1.67 & 0.10 \\
Standing broad jump (cm) & 200.68 & 23.58 & 170.69 & 20.36 & 5.38 & $0.00^{*}$ \\
Bent arm hang (s) & 34.32 & 16.11 & 20.89 & 14.10 & 4.06 & $0.00^{*}$ \\
Sit-ups (reps.) & 26.75 & 3.30 & 5.08 & 2.10 & 3.73 & $0.00^{*}$ \\
Shuttle run 10x5 m (s) & 18.81 & 1.87 & 22.30 & 1.65 & -6.24 & $0.00^{*}$ \\
Plate tapping (s) & 10.03 & 1.45 & 12.09 & 1.14 & -5.88 & $0.00^{*}$ \\
Sit and reach (cm) & 28.20 & 8.31 & 22.85 & 6.79 & 1.92 & $0.05^{*}$ \\
Flamingo balance (number of falls in 60s) & 3.24 & 2.03 & 5.08 & 2.10 & -2.60 & $0.01^{*}$ \\
\hline \multicolumn{2}{c}{ *statistically significant difference at $\mathrm{p} \leq 0.05$} & & &
\end{tabular}

The study also focuses on the frequency of consuming components of the pHDI-10 and nHDI-14. While analysing the pro-healthy diet indicator, more frequent consumption of poultry, legumes as well as fruit and vegetables was noted in PE students. Nursing and physiotherapy students more often had wholemeal bread, groats, cereals and pasta as well as milk and fermented milk products, but the observed differences were not statistically significant (Figure 1).

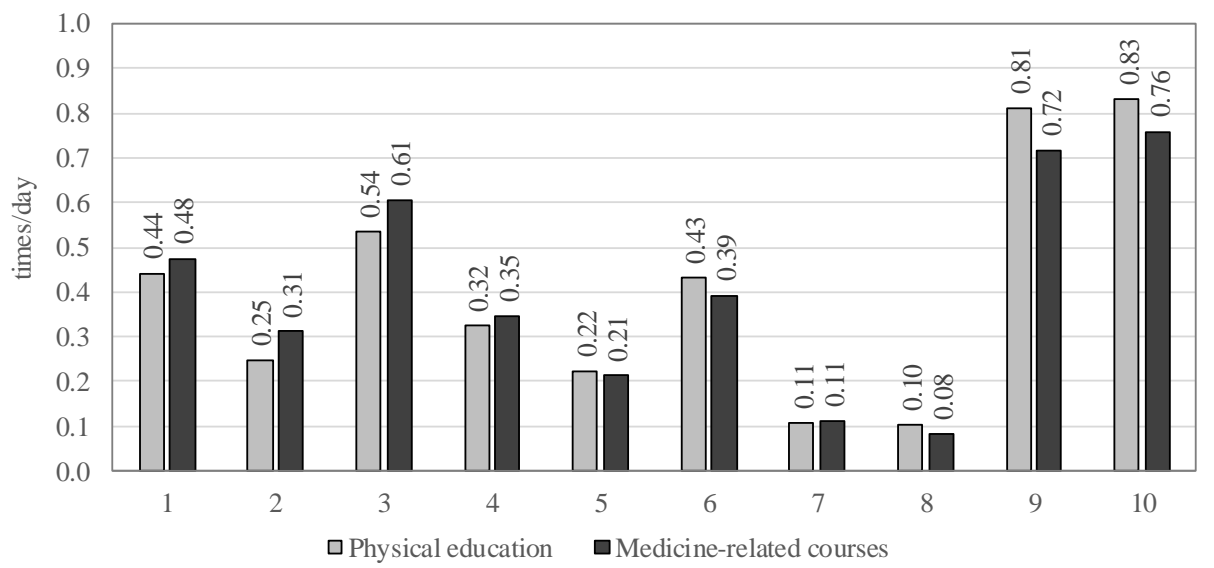

Fig. 1 Frequency of consuming food items from pHDI-10 in PE students and students of medicine-related courses

Key: 1. wholemeal bread; 2. buckwheat, oatmeal, wholemeal pasta or other whole wheat groats; 3 . milk (including flavoured milk, cocoa, milk coffee); 4. fermented milk drinks, e.g. yoghurt, kefir (natural or flavoured); 5. cottage cheese (including smooth cottage cheese, cottage cheese desserts); 6. white meat dishes, e.g. chicken, turkey or rabbit dishes; 7. fish; 8. legume dishes, e.g. bean, peas, soya or lentil dishes; 9. fruit; 10. vegetables

In the case of the non-healthy diet indicator, PE students more often consumed rice and pasta, hard cheese, energy drinks and alcohol, while students of medicine-related courses had such groups of products as white bread, butter, processed meat, red meat and 
sweets more often. Statistically significant differences were noted in the frequency of consuming red meat, energy drinks and alcohol (Figure 2).

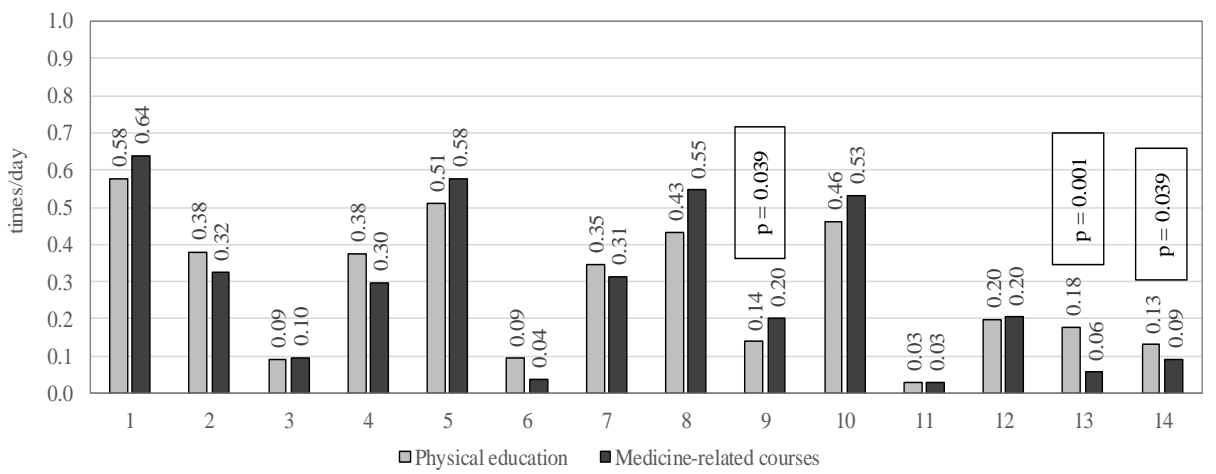

Fig. 2 Frequency of consuming food items from nHDI-14 in PE students and students of medicine-related courses

Key: 1. white bread, e.g. wheat bread, rye bread, wheat-rye bread, toasts, rolls, croissants; 2 . white rice, pasta, groats, e.g. semolina, couscous; 3. fast foods, e.g. chips, hamburgers, pizza, hot dogs; 4. meat or flour fried dishes; 5 . butter eaten with bread or dishes, or used for frying or baking, etc.; 6. lard eaten with bread or dishes, or used for frying or baking, etc.; 7. cheese (including processed cheese, blue cheese); 8. meat, sausages or frankfurters; 9. red meat dishes, e.g. pork, beef, veal, mutton, lamb or venison dishes; 10. sweets and confectionery, e.g. biscuits, cakes, chocolate bars, muesli bars and others; 11. canned meat; 12. sweetened carbonated drinks, e.g. Coca-Cola, Pepsi, Sprite, Fanta, orangeade, lemonade; 13. energy drinks, e.g. 2 KC, Black Horse, Red Bull, Burn, Shot or others; 14. alcoholic beverages

Mean indicators of pro-healthy and non-healthy diets fell within the range of small intensity of nutritional features and, in PE students, were at the level of 4.06 and 3.94 times per day, respectively, while in students of medicine-related courses - at the level of 4.02 and 3.95 times per day, respectively. The maximal value for pHDI-10 was 20 times per day and for nHDI-14 it was 28 times per day. Differences between the groups of students were not statistically significant.

Moreover, on the basis of the results obtained in the KomPAN questionnaire, the current state of knowledge of the examined students about food and nutrition was determined. Regardless of the field of study, the majority of the study participants manifested a sufficient level of nutritional knowledge. However, it was noted that the percentage of students with an insufficient level of knowledge was higher among PE students, while the percentage of students with a good level of knowledge was higher among students of medicine-related courses. However, the obtained differences were not statistically significant (Table 4). 
Table 4 The level of knowledge about food and nutrition among the examined female students

\begin{tabular}{lcccccccc}
\hline & $\begin{array}{c}\text { The level } \\
\text { ef knowledge }\end{array}$ & \multicolumn{2}{c}{ Insufficient } & \multicolumn{2}{c}{ Sufficient } & & Good & \multicolumn{2}{c}{$\begin{array}{c}\chi^{2} \text { Pearson's } \\
\text { test }\end{array}$} \\
\cline { 2 - 10 } & $\mathrm{n}$ & $\%$ & $\mathrm{n}$ & $\%$ & $\mathrm{n}$ & $\%$ & $\chi^{2}$ & $\mathrm{p}$ \\
\hline Physical education & $21 *$ & 20.2 & $72^{*}$ & 69.2 & $11 *$ & 10.6 & 0.35 & 0.84 \\
Medicine-related courses & $20 *$ & 18.7 & $73 *$ & 68.2 & $14 *$ & 13.1 & & \\
\hline
\end{tabular}

*The numbers in the above table are lower than those given in the research methods because the KomPAN survey was not completed by all surveyed students

\section{DISCUSSION}

Depending on the profile of their studies, students are subject to different requirements. Due to their interests, nursing and physiotherapy students should present a high level of health awareness and motivation and should manifest a high level of knowledge about proper diets and the role of physical activity in maintaining health. In turn, PE students should present a high level of physical fitness which can be achieved during obligatory sports classes at university but also while attending sport-specific training sessions. The results of our research confirmed the fact that PE students demonstrated higher levels of physical fitness than the students of medicine-related courses. Pugh et al. (2019) and Stephens, Cochran, Hall, \& Olsen (2012) dealt with the assessment of physical fitness and performance among students of medicine-related courses from Australia and USA and concluded that their physical fitness is insufficient and its improvement may increase their readiness for future work.

A high level of physical fitness correlates strongly with body build. In physically active persons, the percentage of lean body mass, including muscle mass, should be high, while excessive fat tissue is an unfavourable factor (Čabrić, Krakowiak, \& Krakowiak, 2010).

Our research results revealed that differences in body composition between PE students and students of medicine-related courses were significant. PE students had healthier body composition. They manifested higher values of body height, muscle mass and fat-free body mass, while nursing and physiotherapy students had more body fat. Similar results regarding body composition among female PE students compared to other fields of study were presented by Čabrić et al. (2010) and Resende, Resende, Tavares, Santos, \& Barreto-Filho, (2010). What was alarming in the results obtained in our research was a high level of fat in women from medical fields of study. Theoretically, they should present a high level of knowledge about a negative influence of excessive fat tissue on human health. However, the results of our research and the findings of other authors revealed that this group often manifested excessive adiposity (van den Berg, Okeyo, Dannhauser, \& Nel, 2012; Lehmann, von Lindeman, Klewer, \& Kugler, 2014).

Body composition depends not only on physical activity, but also on a proper diet which is one of basic factors positively influencing health state, proper physical development and well-being. Academic youth is particularly prone to improper nutrition both due to irregular classes and because of financial and organisational problems regarding meal preparation. Due to the fact that compared to other fields of study, students from the University of Physical Education manifest much higher levels of 
physical fitness, they should pay particular attention to the application of nutritional guidelines, taking into account an increased demand for energy and selected nutrients. Moreover, owing to the preparation for future careers, students of nursing and physiotherapy should feel responsible not only for their health but also for the whole society and should consciously shape their nutritional habits. Our own research showed that there were no considerable differences in the diet between the compared groups. Simultaneously, it was concluded that the intensity of both pro-healthy and non-healthy features was most frequently low in both groups of students.

Irregularities in the students' diet may result from their insufficient knowledge about it. Despite constant education in this area, beginning with information from parents as well as from teachers at school and university to information from mass media, numerous studies have indicated low levels of knowledge among students regarding proper nutrition (Badrasawi, Shraim, \& Al-Atrash, 2018; Ozdoğan \& Ozcelik, 2011; van den Berg et al., 2012). Our research revealed only a sufficient level of knowledge about nutrition among all groups of students under investigation. Taking into account the fact that the research was carried out on $1^{\text {st }}$ - and $2^{\text {nd }}$-year students, it may be assumed that in the course of studies this knowledge will be extended, which may be related to attending classes regarding human nutrition. Kołłajtis-Dołowy \& Boniecka (2007) observed that nutritional behaviours of female students who attended classes about nutrition were more often compliant with nutritional guidelines compared to the group of female students who did not attend such classes. The study by Ozdoğan \& Ozcelik (2011) carried out on Turkish students of physical education and our own study (Popławska, Dmitruk, Kunicka, Dębowska, \& Hołub, 2018) on differences in the level of knowledge between $1^{\text {st }}$ - and last-year students of physical education revealed that in the course of university studies, the knowledge about food and nutrition increased.

The findings of the present study as well as results obtained by other researchers indicate the need for further educational activities aimed at promoting rational diets among academic youth.

\section{CONCLUSIONS}

Female PE students manifested healthier body composition. They had greater muscle mass, bone tissue mass, and fat-free body mass, and body height as morphologic characteristic, while nursing and physiotherapy students had more fat.

The comparison of the data obtained in the research on physical fitness revealed that PE students achieved better results in all the physical fitness tests except for the handgrip strength test.

No significant differences were noted between PE students and students of nursing and physiotherapy regarding the frequency of consuming products included in the prohealthy and non-healthy indices.

The level of knowledge about food and nutrition was sufficient in the majority of students, regardless of their field of study. 


\section{REFERENCES}

Badrasawi, M.M., Shraim, N.Y., \& Al-Atrash, M.H. (2018). Knowledge of physical education students about nutrition: a cross-sectional study from Palestine. International Journal of Nutrition Pharmacology Neurological Diseases, 8, 101-107.

Čabrić, M., Krakowiak, H., \& Krakowiak, A. (2010). Traits of body musculature in students of medicine and physical education. Medical and Biological Sciences, 24(1), 19-24.

Eurofit. European Test of Physical Fitness (1988). Rome: Council of Europe, Committee for the Development of Sport

Eurostat (2014). Body mass index (BMI) by sex, age and educational attainment level. Retrieved May 20, 2019, from the World Wide Web: http://appsso.eurostat.ec.europa.eu/nui/show.do?dataset=hlth_ehis_ bm1e\&lang=en

Feldman, L., Harvey, B., Holowaty, P., \& Shortt, L. (1999). Alcohol use beliefs and behaviors among high school students. Journal of Adolescent Health, 24, 48-58.

Gawęcki, J, (ed.) (2014). Kwestionariusz do badania poglądów i zwyczajów żywieniowych oraz procedura opracowania danych. (Questionnaire for analysing attitudes to nutritional habits and opinions and the procedure for data analysis). Warszawa: Zespol Behawioralnych Uwarunkowan Zywienia, Komitet Nauki o Zywieniu Czlowieka Polskiej Akademii Nauk. In Polish.

Gosh, S., \& Bouchard, C. (2017). Convergence between biological, behavioural and genetic determinants of obesity. Nature Reviews Genetics, 18, 731-748.

Jakičić, J.M., \& Otto, A.D. (2006). Treatment and prevention of obesity: what is the role of exercise? Nutrition Reviews, 64, 57-61.

Joshi, P., Cole, K., \& Overton M. (2016). Trends in sedentary behaviors among high school students: analysis of television and other screen-time activities. Journal of Physical Education and Sport, 16(4), 1142-1145.

Kołłajtis-Dołowy, A., \& Boniecka, I. (2007). Pro-health nutritional behaviors of selected group of students of the Medical University of Warsaw. Roczniki PZH, 58(1), 273-278.

Lehmann, F., von Lindeman, K., Klewer, J., Kugler, J. (2014). BMI, physical inactivity, cigarette and alcohol consumption in female nursing students: a 5-year comparison. BMC Medical Education, 14, 82-87.

Mazurek Melnyk, B., Slevin, C., Militello, L., Teall, A., \& McGovern, C. (2016). Physical health, lifestyle beliefs and behaviors, and mental health of entering graduate health professional students: Evidence to support screening and early intervention. Journal of the American Association of Nurse Practitioners, 28, 204-211.

Ozdoğan, Y., \& Ozcelik, A.O. (2011). Evaluation of the nutrition knowledge of sports department students of universities. Journal of the International Society of Sports Nutrition 8, 11-19.

Pérusse-Lachance, E., Treblay, A., \& Drapeau, V. (2010). Lifestyle factors and other measure in Canadian university community. Applied Physiology, Nutrition Metabolism, 35, 498-506.

Popławska, H., Dmitruk, A., Kunicka, I., Dębowska, A., \& Hołub, W. (2018). Nutritional habits and knowledge about food and nutrition among physical education students depending on their level of higher education and physical activity. Polish Journal of Sport and Tourism, 25(3), 35-41.

Podstawski, R. (2013). Secular trends in aerobic fitness test performance of physically inactive young male (2000-2006). Journal of Physical Education and Sport, 1, 73-77.

Pugh, J.D., Cormack, K., Gelder, L., Wiliams, A.M., Twigg, D.E., \& Blazevich A.J. (2019). Exercise, fitness and musculoskeletal health of undergraduate nursing students: A cross-sectional study. Journal of Advanced Nursing, 75, 2110-2121.

Resende, Mde. A., Resende. R.B., Tavares, Rda. S., Santos, C.R., \& Barreto-Filho, JA. (2010). Comparative study of the pro-atherosclerotic profile of students of medicine and physical education. Arquivos Brasileira De Cardiologia, 95(1), 21-29.

Saczuk, J., Wasiluk, A., Wilczewski, R., \& Wilczewski, A. (2016). Differences in body build and physical fitness of PE Students from the Faculty of Physical Education and Sport in Biala Podlaska in the years 1989, 2004, and 2014. Polish Journal of Sport and Tourism, 23, 212-220.

Stephens, M.B., Cochran, G., Hall, J.M., \& Olsen, C. (2012). Physical fitness during medical school: a 4-year study at the Uniformed Services University. Family Medicine, 44(10), 694-697.

Tsitsimpikou, Ch., Tsarouhas, K., Vasilaki, F., Papalexis, P., Dryllis, G., Choursalas, A., et al. (2018). Health risk behaviors among high school and university adolescent students. Experimental and Therapeutic Medicine, 16, 3433-3438. 
Uzunović, S., Šekeljić, G., Marković, J., Nemec, P., Piršl, D., Nemec, V., \& Stošić, D. (2019). Influence of obesity on schoolgirls motor skill performance. Facta Universitatis Series Physical Education and Sport, 17(1), 89-100.

van den Berg, V., Okeyo, A., Dannhauser, A., Nel, M. (2012). Body weight, eating practices and nutritional knowledge among university nursing students, Eastern Cape, South Africa. The African Journal of Primary Health Care \& Family Medicine, 4(1), 323-332.

\section{SASTAV TELA, FIZIČKI FITNES, PREHRAMBENE NAVIKE I ZNANJE O NAMIRNICAMA I ISHRANI STUDENTKINJA FIZIČKOG VASPITANJA I ODABRANIH KURSEVA VEZANIH ZA MEDICINU}

Cilj rada bio je da se uporedi telesni sastav, fizički fitnes, prehrambene navike $i$ znanja o hrani $i$ ishrani između studentkinja fizičkog vaspitanja (PE) i studentkinja medicine i fizioterapije. Istraživanje je sprovedeno 2018. $i$ obuhvatilo je 137 studentkinja fizičkog vaspitanja $i 115$ studentkinja medicine $i$ fizioterapije iz Biali Podlaska, Poljska. Sastav tela je procenjen metodologijom analize bioimpedance. Fizički fitnes je procenjen upotrebom Eurofit baterije testova. Prehrambene navike $i$ znanje o namirnicama i ishrani procenjeni su korišćenjem upitnika KomPAN, što je omogućilo utvrđivanje dva indeksa, tj., indeksa zdrave ishrane (pHDI-10) i indeksa nezdrave ishrane (nHDI-14). Razlike u telesnom sastavu, fizičkom fitnesu i prehrambenim navikama procenjene su korišćenjem Studentovog t-testa ili Mann-Whitney U testa. Razlike u nivou nutricionističkog znanja između ispitivanih grupa ocenjene su $\chi^{2}$ testom. Kod studentkinja fizičkog vaspitanja utvrđen je bolji sastav tela i viši nivo fizičkog fitnesa. Nivo znanja o namirnicama i ishrani bio je zadovoljavajući kod većine učesnica u istraživanju. Srednji indeksi zdrave i nezdrave ishrane bili su u okviru niskih vrednosti.

Ključne reči: razvoj tela, fizički fitnes, ishrana, razlike, studenti 